\title{
ZASTOSOWANIE BADAŃ DYLATOMETRYCZNYCH (DMT) DO OSZACOWANIA SKŁADU GRANULOMETRYCZNEGO GRUNTÓW
}

\author{
Simon Rabarijoely ${ }^{\bowtie}$, Bartosz Kurowski \\ Wydział Budownictwa i Inżynierii Środowiska, Szkoła Główna Gospodarstwa Wiejskiego w Warszawie, Warszawa
}

\begin{abstract}
STRESZCZENIE
W artykule przedstawiono sposób wykorzystania badań dylatometrycznych (DMT) w określaniu składu granulometrycznego gruntów. Sposób ten opracowano na podstawie interpretacji wyników badań DMT z Kampusu SGGW, warszawskiego osiedla Stegny i II linii warszawskiego metra. Wyniki badań DMT porównano z określeniem zawartości procentowej frakcji otrzymanych z badań laboratoryjnych, które interpretowano zgodnie z normami PN-86/B-02480, PN-EN ISO 14688-1 i PN-EN ISO 14688-2. Efektem porównania jest propozycja autorskiej klasyfikacji i nomogramu, które mogą być wykorzystane do rozpoznania rodzaju gruntu na podstawie badań DMT.
\end{abstract}

Słowa kluczowe: klasyfikacja gruntów, badania DMT, interpretacja wyników, nomogram klasyfikacyjny

\section{WSTĘP}

Rozwój technicznej działalności człowieka pociąga za sobą rozwój budownictwa. Sprawia to, że budowane obecnie obiekty inżynieryjne, coraz większe i cięższe, niejednokrotnie posadowione są na gruntach słabych, w tym na gruntach organicznych. Zmusza to projektantów do stosowania coraz bardziej skomplikowanych systemów posadowień tego typu obiektów. W celu dobrania odpowiedniego systemu należy posiadać wiedzę o podłożu, na którym lub w którym obiekt będzie posadowiony. Do tego celu służą badania podłoża gruntowego, które można podzielić na terenowe i laboratoryjne. Badania laboratoryjne mają szereg zalet, takich jak: dokładność, dobrze zdefiniowany stan naprężenia czy możliwość kontrolowania warunków odpływu (Gryczmański, 1995; Pisarczyk, 2014a, 2014b). Jednakże badania terenowe pozwalają na szybsze określenie warunków geotechnicznych, w tym rodzaju i stanu gruntów w podłożu budowli.

W niniejszym artykule podjęto próbę wykorzystania wyników badań dylatometrycznych (DMT) do rozpoznania rodzaju gruntów. Aby osiągnąć ten cel, przeprowadzono analizę archiwalnych badań wykonanych przez Katedrę Geoinżynierii Szkoły Głównej Gospodarstwa Wiejskiego w Warszawie trzech następujących obiektów: Kampusu SGGW, osiedla Stegny i II linii warszawskiego metra.

W dotychczasowej praktyce badania dylatometryczne (DMT) rzadko wykorzystywano do rozpoznania rodzaju gruntów występujących w podłożu. Marchetti, przedstawiając w 1980 roku innowacyjne urządzenie badawcze, zaproponował podział gruntów zależnie od wartości wskaźnika materiałowego $\left(I_{D}\right)$ - tabela 1. Modyfikacja sondy DMT w 1988, 1997, 1998, 1999 i 2008 roku (Hepton,1988; Martin i Mayne, 1997, 1998; Mayne, Schneider i Martin, 1999; Marchetti, Monaco, Totani i Marchetti, 2008), polegająca na zainstalowaniu modułu sejsmicznego, umożliwiła dodatkowo wyznaczanie w badanym podłożu rozkładu prędkości fali poprzecznej. Cruz w 2009 roku wykazał, że zależność pomiędzy $I_{D}, U_{D}$ i $G_{0} / E_{D}$ zwiększa dokładność identyfikacji gruntów

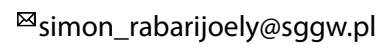


Tabela 1. Klasyfikacja gruntów na podstawie wskaźnika materiałowego $\left(I_{D}\right)$ - Marchetti (1980)

Table 1. Soil classification based on the material index $\left(I_{D}\right)$ - Marchetti (1980)

\begin{tabular}{llc}
\hline Grunty - Soils & Rodzaj gruntu - Soil type & Wskaźnik materiałowy, $I_{D}-$ Material index, $I_{D}$ \\
\hline & torf / ił wrażliwy - peat / sensitive clays & $<0,10$ \\
Grunty organiczne & ił - clay & $0,10-0,35$ \\
i spoiste & ił pylasty - silty clay & $0,35-0,60$ \\
Organic and cohesive & glina pylasta - clayey silt & $0,60-0,90$ \\
soils & pył - silt & $0,90-1,20$ \\
& pył piaszczysty - sandy silt & $1,20-1,80$ \\
\hline Grunty niespoiste & piasek pylasty - silty sand & $1,80-3,30$ \\
Non-cohesive soils & piasek - sand & $>3,30$ \\
\hline
\end{tabular}

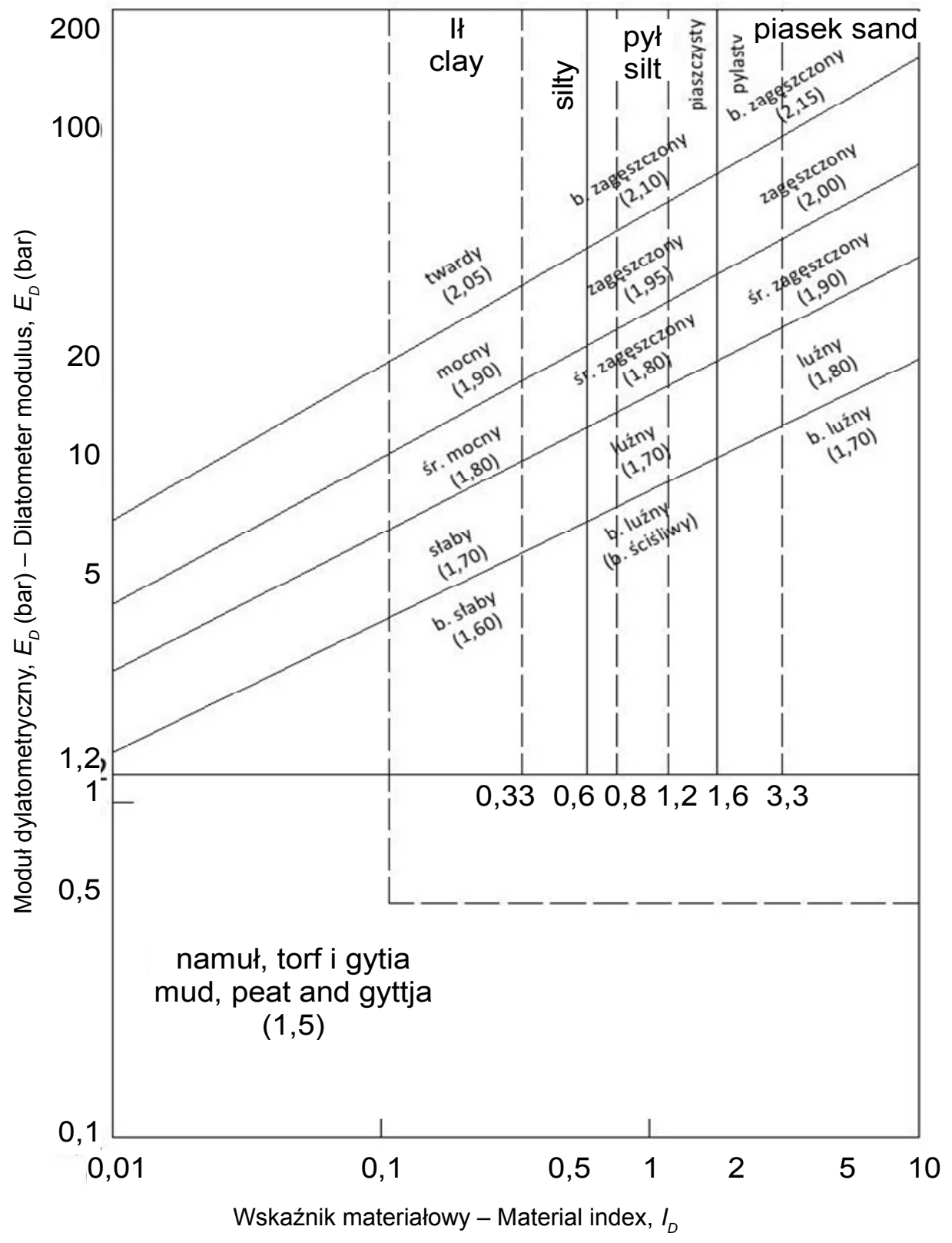

Rys. 1. Nomogram do klasyfikacji gruntów z badań dylatometrycznych oraz określania znormalizowanego ciężaru objętościowego gruntu (Marchetti i Crapps, 1981)

Fig. 1. Chart for estimating soil type and unit weight for soil - normalized to $\gamma_{w}$ (Marchetti \& Crapps, 1981) 
Rabarijoely, S. i Kurowski, B. (2017). Zastosowanie badań dylatometrycznych (DMT) do oszacowania składu granulometrycznego gruntów. Acta Sci. Pol. Architectura, 16 (1), 13-23. doi: 10.22630/ASPA.2017.16.1.02.

z pomiarów SDMT (Cruz, 2009). Z badań przeprowadzonych przez Cruza, Devincenziego i Viana da Fonseca (2006) oraz Cruza (2010) wynika, że interpretując pomiary SDMT, można uzyskać dobrą zgodność z makroskopowym rozpoznaniem gruntu podczas wierceń i z laboratoryjnymi badaniami identyfikacyjnymi do rozpoznania rodzaju gruntów dla celów inżynierskich.

Marchetti i Crapps (1981) opracowali monogram (rys. 1), który w nowy sposób klasyfikował grunty zależnie od wskaźnika materiałowego $\left(I_{D}\right)$ i modułu dylatometrycznego $\left(E_{D}\right)$. Nomogram został opracowany głównie na podstawie wyników badanych gruntów mineralnych. Nomogram można również wykorzystać do określenia stanu zagęszczenia gruntów piaszczystych i stanu plastyczności gruntów spoistych oraz ciężarów objętościowych gruntów.

Młynarek, Tschuschke, Lunne i Sanglerat (1993), Młynarek (2007) oraz Młynarek, Wierzbicki i Long (2008) prowadzili badania, których celem było określenie rodzaju gruntów na podstawie badań dylatometrycznych. Wymienieni badaczy stwierdzili, że w interpretacji badań dylatometrycznych, oprócz wskaźnika materiałowego $\left(I_{D}\right)$ i modułu dylatometrycznego $\left(E_{D}\right)$, należy uwzględnić wskaźnik prekonsolidacji (OCR).

\section{CHARAKTERYSTYKA BADANYCH GRUNTÓW}

\section{Obiekt: Kampus SGGW}

Biorąc pod uwagę właściwości fizyczne i mechaniczne gruntów, na terenie Kampusu SGGW wydzielono w podłożu 5 warstw geotechnicznych (rys. 2). Warstwe I tworzą utwory fluwioglacjalne zlodowacenia Warty $\left({ }^{\mathrm{fg}} \mathrm{Q}_{\mathrm{p}} \mathrm{W}\right)$ - piaski średnie i drobne, średnio zagęszczone o stopniu zagęszczenia $I_{D}=0,35-0,55$ oraz piaski gliniaste, gliny piaszczyste i pyły w stanie twardoplastycznym o stopniu plastyczności $I_{L}=0,15-0,20$. Warstwę II stanowią osady ablacyjne lądolodu zlodowacenia Warty $\left({ }^{b} \mathrm{Q}_{\mathrm{p}} \mathrm{W}\right)$ - piaski średnie i drobne średnio zagęszczone o $I_{D}=0,3-0,5$ oraz gliny piaszczyste (spływowe) i piaski gliniaste w stanie twardoplastycznymi o $I_{L}=0,0-0,20$ oraz w stanie plastycznym o $I_{L}=0,25-0,54$. Warstwa III to brązowa glina glacjalna $\mathrm{z}$ okresu zlodowacenia Warty $\left({ }^{\mathrm{g}} \mathrm{QpW}\right)-$ gliny piaszczyste w stanie twardoplastycznym o $I_{L}=0,0-0,11$. Warstwę IV stanowi szara glina

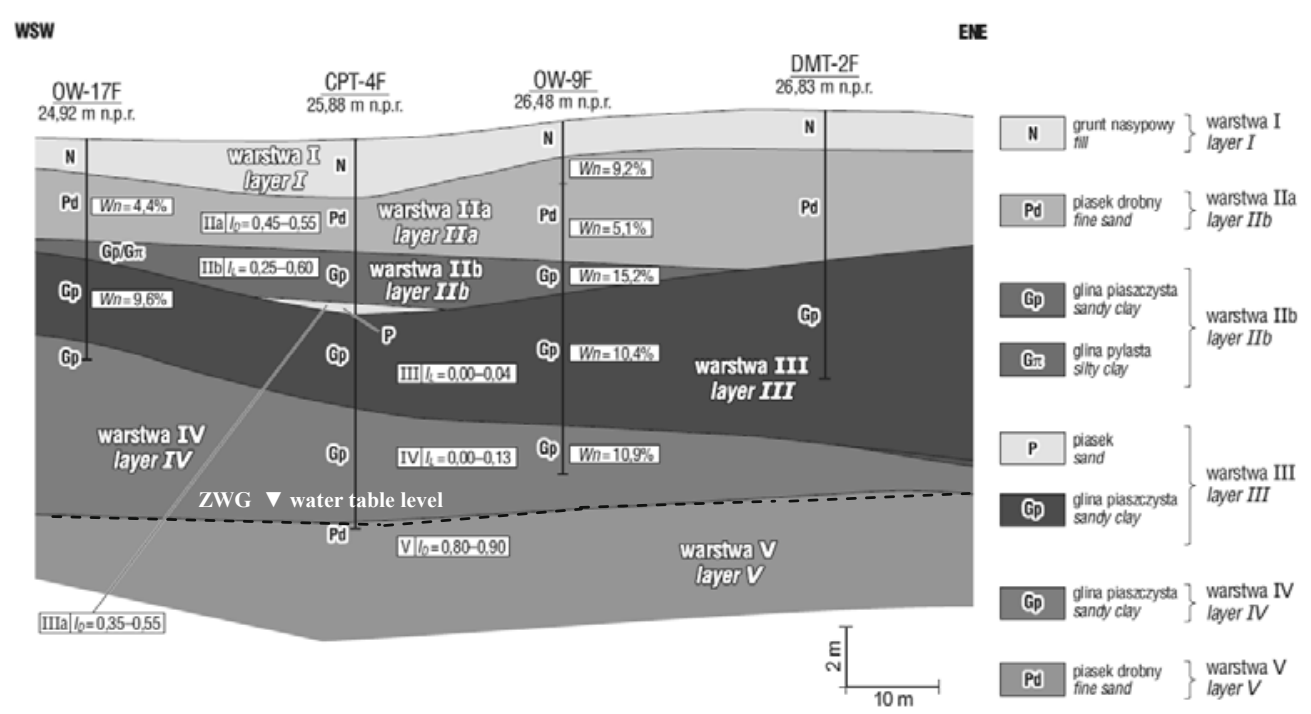

Rys. 2. Typowy przekrój geotechniczny kampusu SGGW: $w_{n}$ - wilgotność naturalna, $I_{D}$ - stopień zagęszczenia, $I_{L}-$ stopień plastyczności, m n.p.r. - metrów nad poziomem Wisły (Rabarijoely i in., 2008)

Fig. 2. Typical geotechnical cross section SGGW Campus: $w_{n}-$ moisture content, $I_{D}$ - relative density, $I_{L}$ - liquidity index, m n.p.r. - meters above Vistula River level (Rabarijoely et al., 2008) 
Rabarijoely, S. i Kurowski, B. (2017). Zastosowanie badań dylatometrycznych (DMT) do oszacowania składu granulometrycznego gruntów. Acta Sci. Pol. Architectura, 16 (1), 13-23. doi: 10.22630/ASPA.2017.16.1.02.

glacjalna z okresu zlodowacenia Odry $\left({ }^{\mathrm{g}} \mathrm{QpO}\right)$ - gliny piaszczyste $\mathrm{z}$ głazikami w stanie twardoplastycznym o $I_{L}=0,0-0,12$. Warstwy III i IV są podobne pod względem plastyczności, ale wyraźnie różnią się zawartością frakcji piaskowej. Gliny piaszczyste warstwy III zawierają kilka procent więcej frakcji piaskowej, co łącznie z analizą wyników sondowań CPT i DMT było podstawą propozycji rozdzielenia tych warstw w podłożu. Warstwę V stanowią osady rzeczne interglacjału mazowieckiego $\left({ }^{\mathrm{f}} \mathrm{Q}_{\mathrm{p}} \mathrm{M}\right)$ - piaski drobne i średnie, w stropie warstwy bardzo zagęszczone o $I_{D}=0,8-0,9$ (rys. 2). Gliny zwałowe o współczynniku prekonsolidacji OCR $=3-7$ są podobne pod względem plastyczności, ale wyraźnie różnią się zawartością frakcji piaskowej (Dokumentacja geotechniczna..., 2000, 2001, 2002).

Na rysunku 3 przedstawiono wskaźniki dylatometryczne $\left(I_{D}, K_{D}\right)$ oraz moduł dylatometryczny $\left(E_{D}\right)$ z badań dylatometrem DMT.
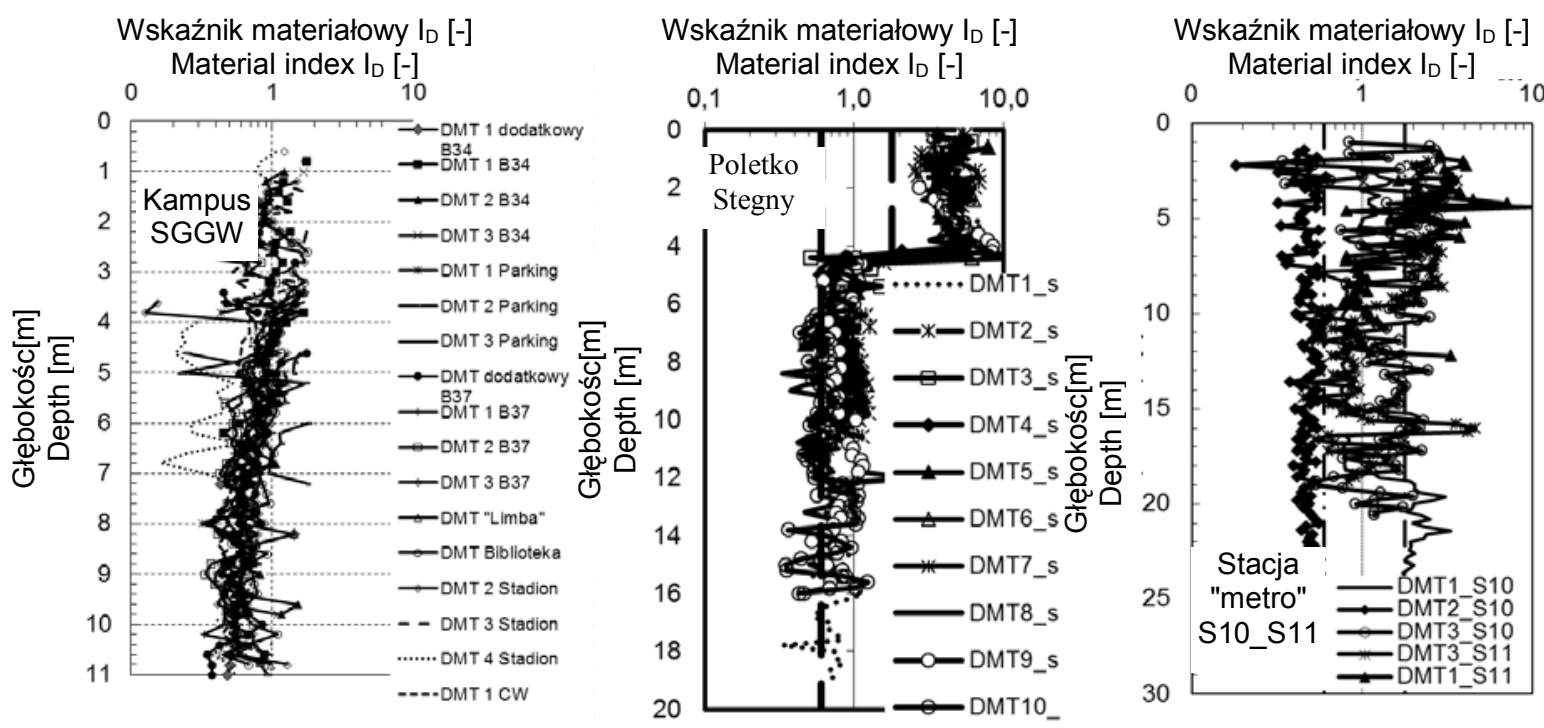

Rys. 3. Profile $I_{D}, K_{D}$ i $E_{D} \mathrm{z}$ badań DMT przeprowadzonych na terenie Kampusu SGGW w Warszawie oraz na skarpie warszawskiej (kościół)

Fig. 3. Profiles of $I_{D}, K_{D}$ and $E_{D}$ indexes from the DMT tests carried out for the subsoil of the SGGW Campus and Warsaw slope (church)

\section{Obiekt: osiedle Stegny}

Teren poletka doświadczalnego Stegny położony jest w dolinie Wisły, na tarasie nadzalewowym praskim, na wysokości względnej od 5 do $10 \mathrm{~m}$ nad poziomem „0" Wisły. Obszerne badania terenowe z wykorzystaniem m.in. dylatometru Marchettiego (rys. 1) wykazały, że w podłożu występują prekonsolidowane iły plioceńskie $(\mathrm{OCR}=$ od 3,0 do 6,5), charakteryzujące się wilgotnością w zakresie od 21,4 do 30,1\%, wartościami granicy płynności $\left(w_{L}\right)$ od 38,5 do $87,4 \%$ i granicy plastyczności $\left(w_{P}\right)$ od 20,9 do $41,0 \%$. Biorąc pod uwagę wilgotność naturalną iłów, należy je zaliczyć do gruntów w stanie zwartym lub półzwartym. Z badań przeprowadzonych przez Rabarijoely’ego, Jabłonowskiego, Falkowskiego i Garbulewskiego (2008) wynika, że podstawowe właściwości iłów plioceńskich, a w zasadzie mio-pliceńskich zależą od zawartości frakcji iłowej.

\section{Obiekty: stacje II linii warszawskiego metra}

W pracy do analizy wybrano stacje: S6 - Bema, S9 - Rondo ONZ, S10 - Marszałkowska, S11 - Nowy Świat. Teren ten znajduje się na wysoczyźnie polodowcowej, w Niecce Mazowieckiej powstałej w paleogenie. 
Rabarijoely, S. i Kurowski, B. (2017). Zastosowanie badań dylatometrycznych (DMT) do oszacowania składu granulometrycznego gruntów. Acta Sci. Pol. Architectura, 16 (1), 13-23. doi: 10.22630/ASPA.2017.16.1.02.

W obrębie stacji S6 występują następujące osady trzeciorzędowe: z paleogenu - piaski, żwiry, mułki i iły z glaukonitem i fosforytami o miąższości około $66 \mathrm{~m}$, z oligocenu - piaski, piaski pylaste, mułki soczewki i przewarstwienia węgla brunatnego, pył węgla brunatnego o miąższości 39-46 m, z miocenu - iły, mułki i piaski (iły pstre) o maksymalnej miąższość $146 \mathrm{~m}$. Stacja S10 posiada takie same osady oligoceńskie jak stacja S6, tyle że o miąższości $70 \mathrm{~m}$. Podobnie jest w przypadku miocenu, tu miąższość sięga 40-47 m. W utworach plioceńskich występują iły pstre (różnobarwne) z wkładkami mułków i piasków pylastych o miąższości około $100 \mathrm{~m}$. Stacja S11 posiada takie same utwory oligoceńskie jak stacja S10 i S11, o miąższości $70 \mathrm{~m}$. Piaski, mułki i iły z pyłem węglowym i wkładkami węgla brunatnego o miąższości około $50 \mathrm{~m}$ reprezentują tu skały miocenu. Iły i iły pylaste oraz mułki przewarstwione piaskiem, lokalnie glinami to grunty plioceńskie.

Przykładowe wyniki badań DMT, wykorzystane w niniejszym artykule, posłużyły autorom do określenia przydatności stworzonego nomogramu w praktyce. Badania te zostały wykonane przez Katedrę Geoinżynierii Szkoły Głównej Gospodarstwa Wiejskiego w Warszawie i dotyczą obiektów zlokalizowanych na terenie kampusu SGGW, poletka doświadczalnego Stegny i obiektów II linii metra warszawskiego. Dane uzyskane podczas badań dylatometrycznych zestawiono $\mathrm{z}$ badaniami laboratoryjnymi i nazwami gruntów uzyskanych za pomoca trójkątów Fereta z norm: PN-86/B-02480. Grunty budowlane. Określenia, symbole, podział i opis gruntów, PNEN ISO 14688-1:2006. Badania geotechniczne. Oznaczenia i klasyfikacja gruntów. Część 1: Oznaczenia i opis, oraz PN-EN ISO 14688-2:2006. Badania geotechniczne. Oznaczenia i klasyfikacja gruntów. Część 2: Zasady klasyfikowania. Na podstawie badań laboratoryjnych na rysunku 4 przedstawiono krzywą uziarnienia ze wszystkich analizowanych obiektów.

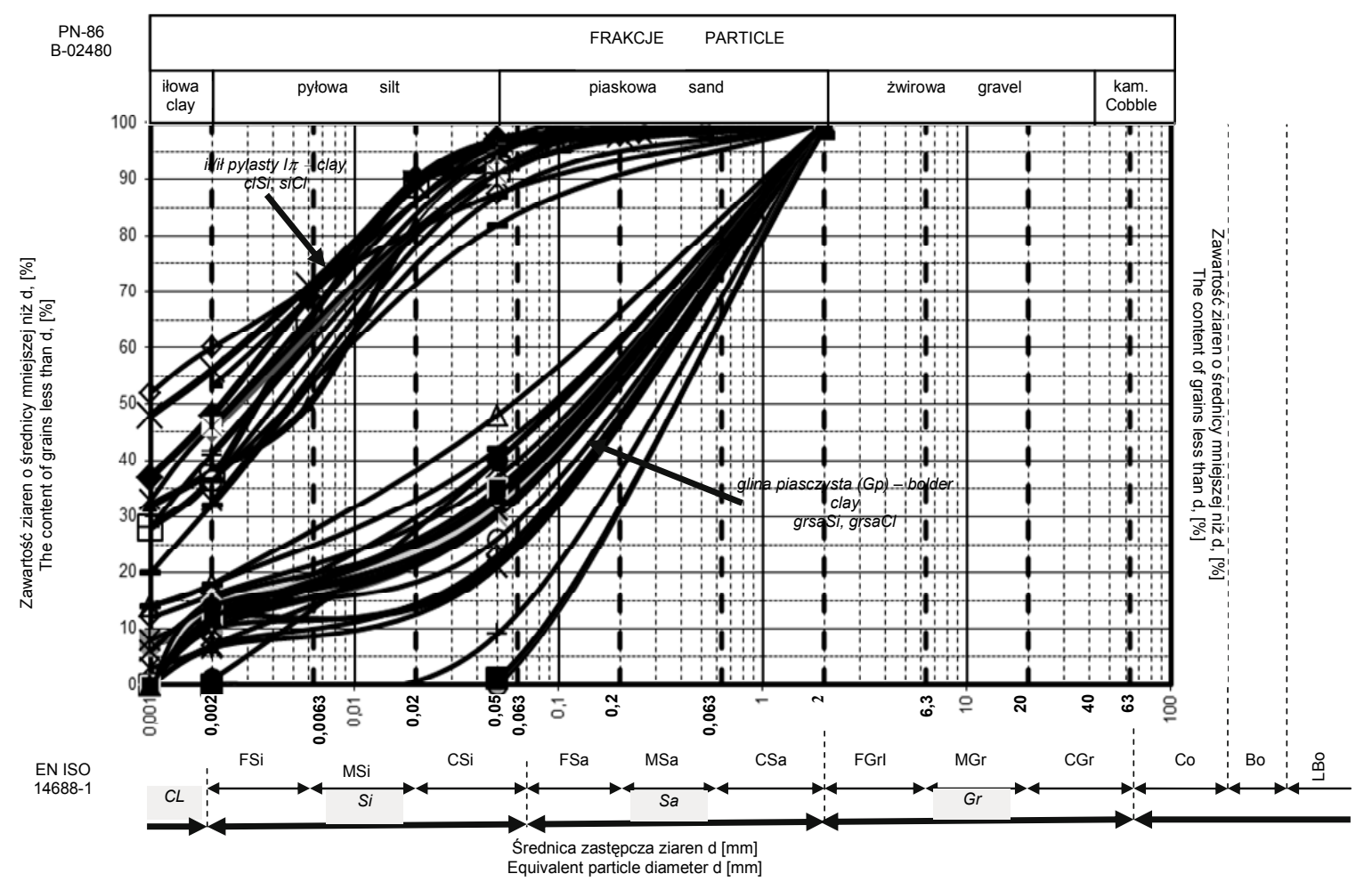

Rys. 4. Krzywa uziarnienia uzyskana $\mathrm{z}$ badań laboratoryjnych dla wszystkich opisywanych obiektów

Fig. 4. Grain size distribution curve obtained from laboratory tests for all described objects 


\section{PROPOZYCJA NOWEGO NOMOGRAMU UMOŻLIWIAJĄCEGO WYZNACZENIE SKŁADU GRANULOMETRYCZNEGO Z BADAŃ DYLATOMETRYCZNYCH (DMT)}

Swoją propozycję nomogramu autorzy opierają na trójkącie Fereta z PN-86/B-02480 (rys. 5) i klasyfikacji gruntów na podstawie badań dylatometrycznych według wartości wskaźnika materiałowego zaproponowanego przez Marchettiego (tab. 2). Odchylenie wskaźnika materiałowego $\left(I_{D}\right)$ według Marchettiego (1997) może występować w różnorodnych formacjach zawartych w klasyfikacji opartej na rozkładzie wielkości ziaren (mieszaninę gliny z piaskiem można opisać jako muł). Można powiedzieć, że wskaźnik materiałowy $\left(I_{D}\right)$ jest miernikiem wpływu zawartości części drobnych, przy czym zapewnia on możliwość zdefiniowania dominujących zachowań w gruntach mieszanych, które zwykle są bardzo trudne do interpretacji, gdyż określona jest tylko wielkość ziaren (Marchetti, 1997).

Tabela 2. Klasyfikacja gruntu na podstawie badań granulometrycznych według wartości wskaźnika materiałowego $\left(I_{D}\right)$ - Marchetti (1980)

Table 2. Soil classification based on the grain size distribution and material index $\left(I_{D}\right)$ - Marchetti (1980)

\begin{tabular}{|c|c|c|c|c|c|c|}
\hline \multirow{9}{*}{ 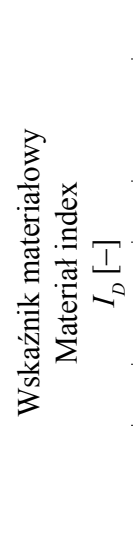 } & \multicolumn{6}{|c|}{ Ił - Clay } \\
\hline & $\mathrm{I}_{\pi}-\mathrm{siCl}$ & $\mathrm{I}-\mathrm{Cl}$ & $\mathrm{I}_{\mathrm{p}}-\mathrm{siCl} / \mathrm{saCl}$ & $\mathrm{G}_{\pi z}-\mathrm{siCl}$ & $\mathrm{G}_{\mathrm{z}}-$ sasiCl & $\mathrm{G}_{\mathrm{pz}}-\mathrm{saCl}$ \\
\hline & $0,1-0,27$ & $0,27-0,33$ & $0,33-0,57$ & $0,57-0,58$ & $0,58-0,59$ & $0,59-0,61$ \\
\hline & \multicolumn{6}{|c|}{ Pył - Silt } \\
\hline & $\mathrm{G}_{\pi}-\operatorname{saclSi}$ & $\mathrm{G}-$ sasiCl & $\mathrm{G}_{\mathrm{p}}-\mathrm{saCl} / \mathrm{clSa}$ & $\pi-\mathrm{Si}$ & $\pi_{\mathrm{p}}-\mathrm{clSi}$ & $\mathrm{P}_{\mathrm{g}}-\mathrm{clSa}$ \\
\hline & $0,61-0,78$ & $0,78-0,79$ & $0,79-0,81$ & $0,81-1,17$ & $1,17-1,74$ & $1,74-1,8$ \\
\hline & \multicolumn{6}{|c|}{ Piasek - Sand } \\
\hline & \multicolumn{2}{|c|}{$\mathrm{P} \pi-\operatorname{siSa}$} & $\mathrm{p}_{\mathrm{d}}-\mathrm{FSa}$ & $\mathrm{p}_{\mathrm{s}}-\mathrm{MSa}$ & \multicolumn{2}{|c|}{$\mathrm{p}_{\mathrm{r}}-\mathrm{CSa}$} \\
\hline & \multicolumn{2}{|c|}{$1,8-3,3$} & $3,3-4,5$ & $4,5-6,5$ & \multicolumn{2}{|c|}{$6,5-10$} \\
\hline
\end{tabular}

Połączenie tabeli z klasyfikacją Marchettiego z trójkątem było możliwe dzięki porozcinaniu trójkąta Fereta na poziome paski zgodnie z nazwami gruntów kolejno występujących w klasyfikacji Marchettiego (tab. 2). Aby było to możliwe, trójkąt odwrócony został w lustrzanym odbiciu względem swojej wysokości (oś prostopadła do boku wyznaczającego zawartość frakcji pyłowej). Następnie na dole każdego paska dorysowano osie z oznaczonymi przedziałami wskaźnika materiałowego $\left(I_{D M T}\right)$ z odpowiednio dobraną skalą (skala zmienna w obrębie różnych gruntów). Niezbędne okazało się dokonanie niewielkich zmian dotyczących szerokości przedziałów. Podziałka $I_{D M T}$ rysowana jest w skali matematycznej, innej jednak dla każdego paska nomogramu. Wynika to ze skoków wielkości $I_{D M T}$ dla poszczególnych gruntów, np. piasek $-I_{D M T}$ od 1,8 do 10, a glina - od 0,57 do 0,61, jeśli zachowamy jedną skalę, to przedział osi dla piasków byłby bardzo duży w porównaniu $\mathrm{z}$ glinami. Stanowi to pewne ułatwienie i uproszczenie, tak by dało się to przedstawić w jednym niewielkim nomogramie. Przerywanymi liniami oddzielono obszary, które rozdzielają poszczególne rodzaje gruntów. Jaki to grunt, opisane jest pod osią $I_{D M T}$. Dodatkowe pionowe linie to przeniesienie przedziałów z trójkąta na oś $\mathrm{I}_{\mathrm{DMT}} \mathrm{i}$ tak przykładowo: ił pylasty mieści się na osi $I_{D M T}$ od 0,1 do 0,27 , tak jak u Marchettiego. Potem punkt przykładowy, np. $I_{D M T}=0,25$ przenosi się na trójkąt i odczytuje skład frakcji. Otrzymany nomogram przedstawiono na rysunku 11. 


\section{INSTRUKCJA KORZYSTANIA Z AUTORSKIEGO NOMOGRAMU UMOŻLIWIAJĄCEGO WYZNACZENIE SKŁADU GRANULOMETRYCZNEGO Z BADAŃ DYLATOMETRYCZNYCH (DMT)}

Aby skorzystać z nomogramu, należy poznać zasady korzystania z niego. Poniżej zaprezentowano krótką instrukcję wyznaczania zawartości poszczególnych frakcji na bazie wskaźnika materiałowego $\left(I_{D M T}\right)$.

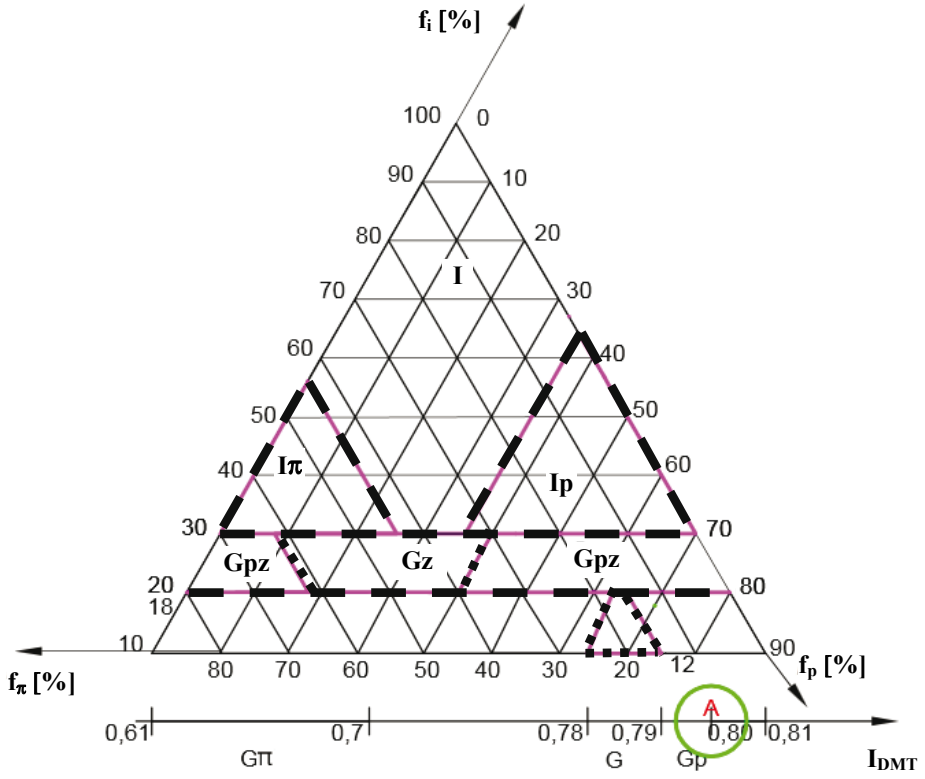

Rys. 5. Rysunek obrazujący korzystanie z nowego nomogramu. Znajdowanie punktu A na osi $I_{D M T}$ (tu $\left.I_{D M T}=0,8\right)$

Fig. 5. Scheme to showing the use of the new nomogram. Finding a point $\mathrm{A}$ on the axis (here $I_{D M T}=0.8$ )
Krok 1: należy odszukać wartość wskaźnika materiałowego $\left(I_{D M T}\right)$ uzyskanego z badań dylatometrycznych na odpowiedniej osi poziomej nomogramu, otrzymując w ten sposób punkt A (rys. 5).

Krok 2: od odnalezionego punktu A na osi $I_{D M T}$ poprowadzić prostą prostopadłą $\mathrm{w}$ górę do podstawy odpowiedniego przedziału z tabeli 2, zawierającego odpowiedni grunt, otrzymując punkt B (rys. 6). Należy podkreślić, że każdy z ,pasków” (przedział) $I_{D M T}$ ma swoją skalę.

Krok 3: przedłużyć prostą do granicy gruntu zgodnie $\mathrm{z}$ kierunkiem prostych wyznaczających zawartość procentową frakcji pyłowej, otrzymując punkt C (rys. 7).

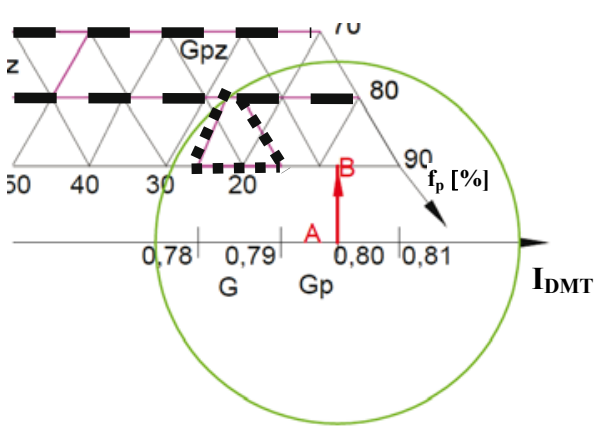

Rys. 6. Rysunek obrazujący korzystanie z nowego nomogramu. Wyznaczenie punktu $B$

Fig. 6. Scheme to showing the use of the new nomogram. Determination of point $\mathrm{B}$

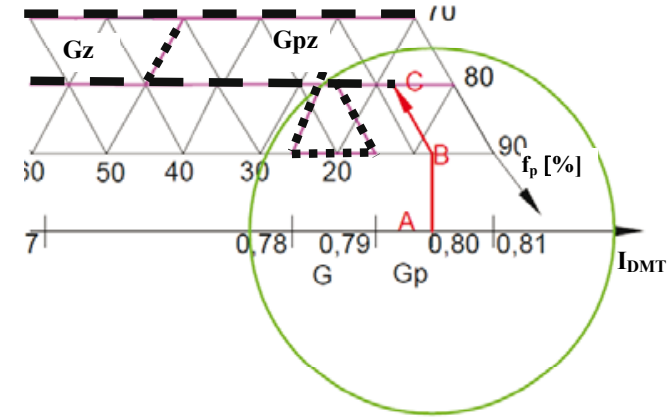

Rys. 7. Rysunek obrazujący korzystanie z nowego nomogramu. Przedłużając prostą równoległą do przebiegu prostej wyznaczającej zawartość frakcji pylastej do granicy danego gruntu, otrzymuje się punkt $\mathrm{C}$

Fig. 7. Scheme to showing the use of the new nomogram. Extension of a line parallel to the course straight designating silty fraction, to the border of the soil yield point $\mathrm{C}$ 
Krok 4: wyznaczyć kolejne dwie proste równoległe do wyznaczonej w kroku 3, pierwszą poniżej 5\% od wyznaczonego punktu $I_{D M T}$, otrzymując punkty B' i C', drugą powyżej $5 \%$, otrzymując punkty B"i C". W ten sposób otrzymuje się obszar bezpieczny. Obszar ten jest zbiorem prawidłowych rozwiązań według nomogramu autora. Dowolny punkt odniesiony do poszczególnych osi zawartości procentowej poszczególnych frakcji prowadzi do odczytania rozwiązania z zamieszczonego rysunku (rys. 8).

Aby dokładnie zobrazować korzystanie z nomogramu, poniżej zaprezentowano sposób jego wykorzystania na konkretnym przykładzie. Skorzystano tu z danych z tabeli 3. Dla obiektu Centrum Wodne SGGW z badania DMT 2 na głębokości $6 \mathrm{~m}$ wyznaczono skład granulometryczny na podstawie wskaźnika materiałowego $I_{D M T}=0,8$.

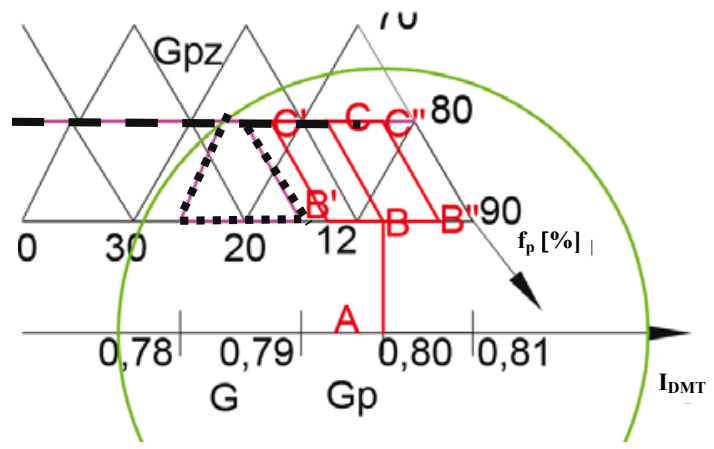

Rys. 8. Rysunek obrazujący korzystanie z nowego nomogramu. Wyznaczenie obszaru bezpiecznego, w którym wyznaczono skład granulometryczny

Fig. 8. Scheme to showing the use of the new nomogram. The designation of a safe area in which we determine the grain size distribution

Tabela 3. Porównanie wartości frakcji granulometrycznej uzyskanej z badań laboratoryjnych z wartościami uzyskanymi z proponowanego nomogramu

Table 3. The comparison of grain size fraction obtained from laboratory tests with the values obtained from the proposed nomogram

Wskaźnik materiałowy $I_{D}=0,8$ obiektu Centrum Wodne SGGW z badania DMT 2 na głębokości $6 \mathrm{~m}$

Material index $I_{D}=0,8$ Centrum Wodne site SGGW from DMT2 test at $6 \mathrm{~m}$ depth

\begin{tabular}{lccc}
\hline $\begin{array}{l}\text { Skład granulometryczny } \\
\text { Grain size distribution }\end{array}$ & $\begin{array}{c}\text { frakcja iłowa } \\
\text { clay fraction }\end{array}$ & $\begin{array}{c}\text { frakcja pyłowa } \\
\text { silt fraction }\end{array}$ & $\begin{array}{c}\text { frakcja piaskowa } \\
\text { sand fraction }\end{array}$ \\
$\begin{array}{l}\text { Badanie laboratorium } \\
\text { Laboratory test }\end{array}$ & $19 \%$ & $13 \%$ & $68 \%$ \\
$\begin{array}{l}\text { Proponowany nomogram } \\
\text { Proposed niomogram }\end{array}$ & $18 \%$ & $12 \%$ & $70 \%$ \\
\hline
\end{tabular}

Autorzy na podstawie rysunku 9 oraz 10 określili skład następująco: 18\% frakcji iłowej, $12 \%$ frakcji pyłowej i $70 \%$ frakcji piaskowej. Badania laboratoryjne uzyskane podczas badań próbki gruntu z tej głębokości określają skład w następujący sposób: 19\% frakcji iłowej, 13\% frakcji pyłowej i 68\% piaskowej. Skład dla frakcji otrzymanych z nomogramu oznaczono punktami D, E, F, otrzymany zaś w laboratorium zaznaczono punktami $\mathrm{G}, \mathrm{H}, \mathrm{I}$. W tym przypadku różnice $\mathrm{w}$ określanym składzie nie przekraczają $2 \% \mathrm{w}$ poszczególnych frakcjach. 


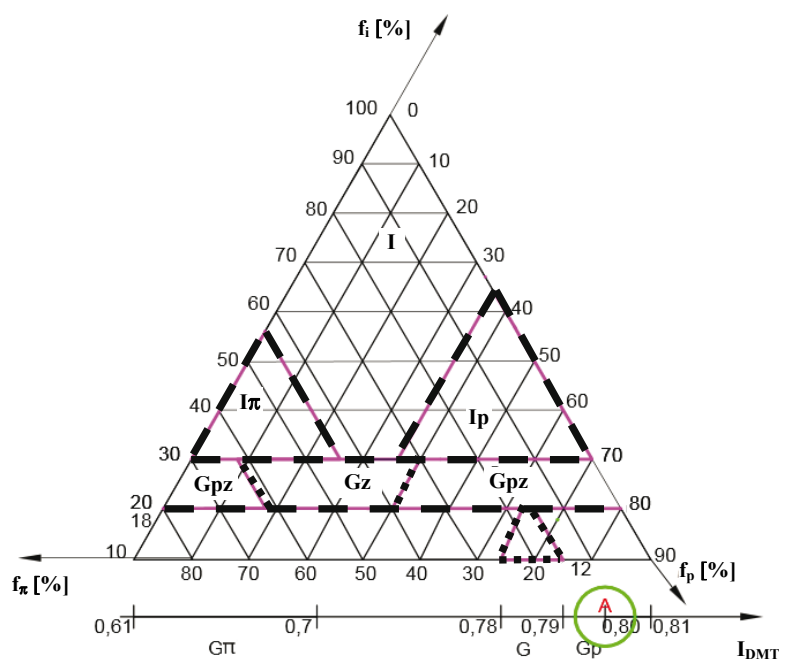

Rys. 9. Rysunek obrazujący korzystanie z nowego nomogramu dla badania obiektu Centrum Wodne

Fig. 9. Scheme to showing the use of the new nomogram from the Centrum Wodne SGGW site

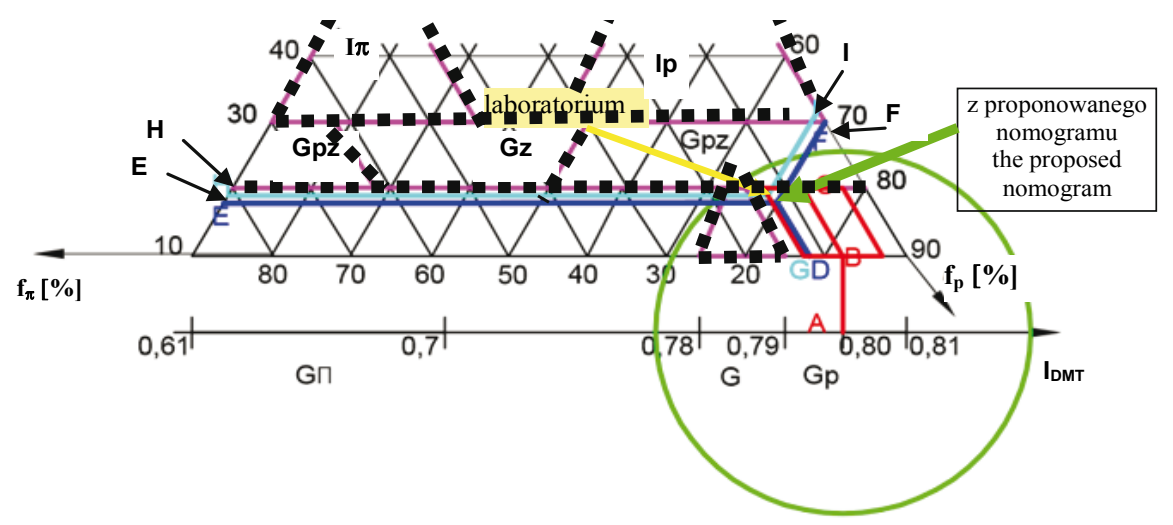

Rys. 10. Rysunek obrazujący korzystanie z nowego nomogramu dla badania obiektu Centrum Wodne SGGW

Fig. 10. Scheme to showing the use of the new nomogram from the Centrum Wodne SGGW site

Przedstawiony powyżej przykład pokazuje, że nomogram może być dość dokładnym narzędziem łączącym badania dylatometryczne z możliwością określenia składu granulometrycznego. Należy pamiętać, że aby uzyskać pewność dotyczącą przydatności tego nomogramu, należy przeprowadzić badania walidacyjne na dużej liczbie danych.

Autorzy na podstawie badan archiwalnych przeprowadzili sprawdzenie poprawności autorskiego nomogramu (rys. 11). Dane z rysunku 12, uzyskane podczas badań przeprowadzonych przez Katedrę Geoinżynierii Szkoły Głównej Gospodarstwa Wiejskiego w Warszawie, wykorzystano do walidacji metody proponowanej przy korzystaniu z nomogramu.

Rysunek 12 zawiera również wyniki uzyskane przez autorów korzystających z własnego nomogramu i przedstawia serię 48 badań DMT (Kampus SGGW: Aula_SDMT3.2, Aula_SDMT3.4, Przejscie_DMT2-1, Przejscie_DMT3-2, StadionSGGW DMT2, Stadion SGGW DMT3, Stadion SGGW DMT4, Centrum Wodne 

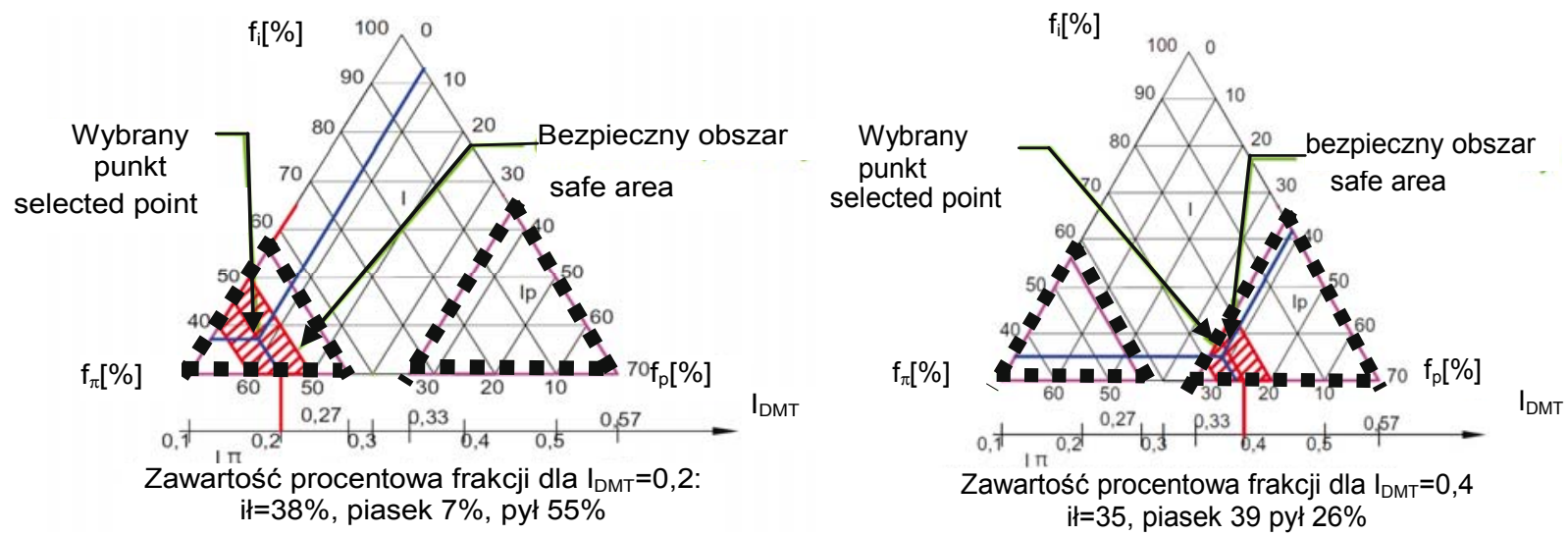

Rys. 11. Propozycja nomogramu umożliwiającego wyznaczenie zawartości poszczególnych frakcji w badaniach dylatometrycznych (DMT)

Fig. 11. The proposal nomogram for determination of the content of each soil fraction based on the DMT tests

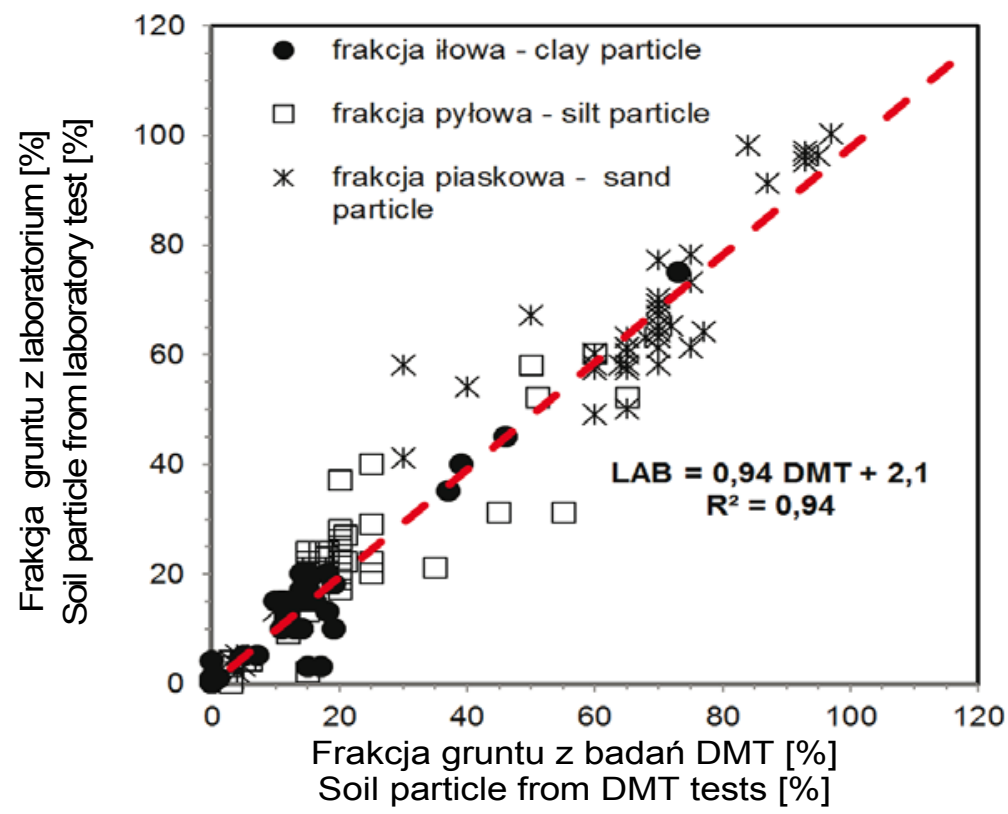

Rys. 12. Porównanie wyników badań granulometrycznych laboratoryjnych z wynikami dylatometru DMT

Fig. 12. The comparison of the grain size distribution obtained from the laboratory and the dilatometer DMT tests results

DMT 1, Centrum Wodne DMT 2, Bud34_SDMT4, Bud34_SDMT4.1, Bud34_SDMT4.2, Bud 37_SDMT1, Bud 37 SDMT1.2, Bud 37 SDMT1.3; Poletko doświadczalne Stegny - Warszawa: DMT1; Obiekt Bielany: Bielany_SDMT8, Bielany_SDMT9; Metro II: S6/DMT3 Bema, S9/DMT2 ONZ, S10/DMT2 Marszałkowska, S11/DMT3 Nowy Świat), dla których wykonano również badania laboratoryjne. Analizy przeprowadzone przez autorów dowodzą, że 70,8\% wyników (34 badania) składu granulometrycznego mieści się w granicy przyjętego błędu (10\%). 
Liczbę prawidłowych wyników obliczono ze wzoru:

$$
x=\frac{x_{p}}{n} \cdot 100 \%
$$

gdzie: $x$ - procentowa zawartość badań prawidłowych w całości serii,

$x_{p}$ - liczba badań prawidłowych w serii,

$n$ - liczba wszystkich badań w serii.

Dodatkowo analizie poddano procentową różnicę pomiędzy składami granulometrycznymi uzyskanymi w laboratorium i odczytanymi z nomogramu. I tak w przypadku frakcji ilastej różnica uzyskana we wszystkich wynikach wyniosła średnio jedynie 3,8\%. W przypadku frakcji pylastej było to $6,0 \%$, a we frakcji piaszczystej $-7,0 \%$. Obliczenia te wykonano, korzystając ze wzoru:

$$
R=\frac{\sum\left|y_{l}-y_{n}\right|}{n}
$$

gdzie: $R$ - średnia różnica w procentowej zawartości danej frakcji pomiędzy wynikiem z laboratorium a odczytanym z nomogramu,

$\sum\left|y_{l}-y_{n}\right|-$ suma wartości bezwzględnej różnicy pomiędzy wynikiem procentowej zawartości danej frakcji z badania w laboratorium a odczytanym z nomogramu,

$n$ - liczba wszystkich badań w serii.

\section{WNIOSKI}

W artykule zaprezentowano autorski nomogram, mający umożliwić odczytanie przybliżonego składu granulometrycznego gruntu na podstawie badań DMT, przy wykorzystaniu wskaźnika materiałowego $\left(I_{D M T}\right)$. Przeprowadzone porównanie wyników uzyskanych w laboratorium z 48 badań DMT wskazuje na zbieżność w przedziale od 4 do $10 \%\left(R^{2}=0,94\right)$ rezultatów, co na obecnym etapie badań można uznać za wynik zadowalający. Mimo to autorzy mają świadomość, że sposób ten aktualnie nie daje stuprocentowej pewności pozwalającej na rekomendowanie go do stosowania w praktyce bez kontrolnego badania laboratoryjnego krzywej uziarnienia gruntu. Należy przeprowadzić jeszcze kolejne analizy sprawdzające na znacznie większej liczbie danych z innych obiektów poza Warszawą, co pozwoli na upewnienie się co do prawidłowości tej metody i wprowadzenie ewentualnych zmian, które pozwolą na zwiększenie poprawności uzyskiwanych wyników.

\section{PIŚMIENNICTWO}

Cruz, I. R. (2009). An evaluation of seismic flat dilatometer and lateral stress seismic piezocone. Praca magisterska. Vancouver: The University of British Columbia.

Cruz, N. (2010). Modelling Geomechanics of Residual Soil with DMT test. Praca doktorska. Porto: Universidade de Porto.

Cruz, N., Devincenzi, M. i Viana da Fonseca, A. (2006). DMT experience in Iberian transported soils. W Proceedings of the 2nd International Flat Dilatometer Conference, Washington (strony 198-204).

Dokumentacja geotechniczna $w$ sprawie warunków gruntowych $i$ wodnych na terenie przeznaczonym pod dwa projektowane budynki laboratoryjno-dydaktyczne SGGW w Warszawie (2000, 2001, 2002). Warszawa: Katedra Geoinżynierii SGGW.

Gryczmański, M. (1995). Wprowadzenie do opisu sprężysto-plastycznych modeli gruntu. Warszawa: Wydawnictwo PAN KILiW IPPT. 
Rabarijoely, S. i Kurowski, B. (2017). Zastosowanie badań dylatometrycznych (DMT) do oszacowania składu granulometrycznego gruntów. Acta Sci. Pol. Architectura, 16 (1), 13-23. doi: 10.22630/ASPA.2017.16.1.02.

Hepton, P. (1988). Shear wave velocity measurements during penetration testing. W Penetration Testing in the UK. Proceedings of the geotechnology conference organized by the Institution of Civil Engineers, Birmingham, on 6-8 July 1988 (strony 275-278). Londyn: Thomas Telford Publishing.

Marchetti, S. (1980). In Situ Tests by Flat Dilatometer. Journal of the Geotechnical Engineering Division, (106), $299-106$.

Marchetti, S. (1997). The Flat dilatometer: Design Applications. W Proceedings of Third International Geotechnical Engineering Conference (strony 421-448). Cairo University. Pobrano z lokalizacji: http://www.marchetti-dmt.it/wp content/ uploads/bibliografia/marchetti_1997_SOA_cairo.pdf

Marchetti, S. i Crapps, D. K. (1981). Flat Dilatometer Manual. Internal Report of G.P.E. Inc.

Marchetti, S., Monaco, P., Totani, G. i Marchetti, D. (2008). In Situ tests by seismic dilatometer (SDMT). W J. E. Laier, D. K. Crapps i M. H. Hussein (red.), From Research to Practice in Geotechnical Engineering (strony 292-311). Reston: American Society of Civil Engineers.

Martin, G. K. i Mayne, P. W. (1997). Seismic flat dilatometer tests in Connecticut Valley Varved clay. Geotechnical Testing Journal, 20(3), 357-361. doi: 10.1520/GTJ19970011.

Martin, G. K. i Mayne, P. W. (1998). Seismic flat dilatometer in Piedmont residual soils. W P. K. Robertson i P. W. Mayne (red.), Proceedings of 1st International Conference on Site Characterization, Atlanta, 2 (strony 837-843). Rotterdam: Balkema.

Mayne, P. W., Schneider, J. A. i Martin, G. K. (1999). Small- and large-strain soil properties from seismic flat dilatometer tests. W M. Jamiolkowski, R. Lancellotta i C. F. Lo Presti (red.), Pre-failure Deformation Characteristics in Geomaterials (strony 419-427). Rotterdam: Balkema.

Młynarek, Z. (2007). Site investigation and mapping in urban area. W Proceedings of the l4th European Conference on Soil Mechanics and Geotechnical Engineering, Madrid (strony 175-202). Amsterdam: IOS Press.

Młynarek, Z., Wierzbicki, J. i Long, M. (2008). Factors affecting CPTU and DMT characteristics in organic soils. W Z. Młynarek, Z. Sikora i E. Dembicki (red.), Geotechnics in maritime engineering: proceedings of the 11th Baltic Sea geotechnical conference on geotechnics in maritime engineering, 11BC 2008, 15-18 September 2008 (strony 407-417). Gdańsk: Polish Committe on Geotechnics \& Gdańsk University of Technology.

Młynarek, Z., Tschuschke, W., Lunne, T. i Sanglerat, G. (1993). Concerning classification of post flotation sediments with CPTU method. W Mécanique des sols appliquée, Colloquium France - Polonaise, Association Universities de Genie Civil, Douai (strony 81-88).

Pisarczyk, S. (2014a). Elementy budownictwa ochrony środowiska. Wydanie 2 popr. Warszawa: Oficyna Wydawnicza Politechniki Warszawskiej.

Pisarczyk, S. (2014b). Geoinżynieria. Metody modyfikacji podłoża gruntowego. Wydanie 2 popr. Warszawa: Oficyna Wydawnicza Politechniki Warszawskiej.

PN-86/B-02480. Grunty budowlane. Określenia, symbole, podział i opis gruntów.

PN-EN ISO 14688-1:2006. Badania geotechniczne. Oznaczenia i klasyfikacja gruntów. Część 1: Oznaczenia i opis.

PN-EN ISO 14688-2:2006. Badania geotechniczne. Oznaczenia i klasyfikacja gruntów. Część 2: Zasady klasyfikowania.

Rabarijoely, S., Jabłonowski, S., Falkowski, T., i Garbulewski, K. (2008). Interpretacja sondowań dylatometrycznych (DMT) z wykorzystaniem analizy bayesowskiej. Przegląd Geologiczny, 56, 4, 322-329. 


\title{
USE OF DILATOMETER TESTS (DMT) TO DETERMINE THE GRAIN SIZE DISTRIBUTION FOR SOIL
}

\begin{abstract}
This paper presents the experiment implementation of dilatometer Marchetti test (DMT) in definition of grain size distribution and present changes in the way the interpretation of these paper in the late years. The paper interpreted the results of the Marchetti dilatometer tests at the Campus of Warsaw University of Life Sciences SGGW, Stegny and Warsaw II Subway Line. Based on the laboratory test results, the grain size distribution was applied on a triangle in accordance with the Polish standard PN-86/B-02480 and European standard PN-EN ISO 14688-1, PN-EN ISO 14688-2 and the grain size distribution. The main advantage of this paper is the author's suggestion that the nomogram will be used to determine the grain size composition of soil on the basis of DMT tests.
\end{abstract}

Key words: soil classifications, DMT tests, results analisis, nomogram chart 